\title{
Küreselleşme, Ekonomik Kalkınma ve Kamu Kesiminin Demokratikleşme Seviyesi Üzerine Etkisi
}

\author{
Mustafa Güder a, b, Mehmet Metin Dam
}

Özet

Bu çalışmada, Yeni Sanayileşen Ülkeler (Brezilya, Çin, Hindistan, Endonezya, Malezya, Meksika, Filipinler, Güney Afrika, Tayland, Türkiye) için küreselleşme, ekonomik kalkınma ve ekonomideki kamu kesimi büyüklüğünün demokratikleşme seviyesi üzerindeki etkisi panel veri analizi yöntemiyle 2003-2017 dönemi yıllık verileri kullanılarak test edilmiştir. Değişken olarak Freedom House Endeksi, KOF Endeksi, kişi başına düşen milli gelir ve kamu kesimi toplam nihai tüketim harcamalarının gayri safi yurtiçi hasıla içindeki payı kullanılmıştır. Serilerin durağanlığı, ikinci kuşak birim kök testlerinden Pesaran (2007) tarafından geliştirilen CIPS panel birim kök testiyle sınanmıştır. Ayrıca, çalışmada Driscoll-Kraay Model Tahmini yaklaşımı kullanılmış ve nedensellik ilişkisi Dumitrescu ve Hurlin (2012) testiyle tahmin edilmiştir. Panel veri analizi sonuçlarına göre demokratikleşme seviyesi üzerinde; küreselleşmenin negatif, ekonomik kalkınma ve kamu kesimi büyüklüğünün ise pozitif etkisinin olduğu tespit edilmiştir. Ayrıca ekonomik kalkınmadan kamu kesimi büyüklüğüne doğru tek yönlü bir nedensellik ilişkisi olduğu sonucuna ulaşılmıştır.
Anahtar Kelimeler

Demokratikleşme

Küreselleşme

Ekonomik Kalkınma

Kamu Kesimi

Makale Hakkında

Geliş Tarihi: 28.06.2021

Kabul Tarihi: 15.12.2021

Doi: 10.18026/cbayarsos.958906

\section{The Effect of Globalization, Economic Development and the Public Sector on the Level of Democratization}

\section{Abstract}

In this study, the effect of globalization, economic development and the size of the public sector in the economy on the level of democratization for the Newly Industrialized Countries (Brazil, China, India, Indonesia, Malaysia, Mexico, Philippines, South Africa, Thailand, Turkey) was tested with panel data analysis method using the 2003-2017 period annual data. Freedom House Index, KOF Index, per capita national income and share of the public sector total final consumption expenditures in the gross domestic product were used as variables. The stationarity of the series was tested with the CIPS panel unit root test, one of the second generation unit root tests, developed by Pesaran (2007). In addition, the Driscoll-Kraay Model Estimation approach was used in the study and the causality relationship was estimated by Dumitrescu and Hurlin (2012) test. According to panel data analysis results, it has been determined that globalization has a negative effect, whereas the size of the public sector in the economy and economic development has a positive effect above the level of democratization. It has also been concluded that there is a one-way causality relationship from economic development to the size of the public sector.
Keywords

Democratization

Globalization

Economic Development

Public Sector

About Article

Received: 28.06.2021

Accepted: 15.12 .2021

Doi: 10.18026/cbayarsos.958906 


\section{Giriş}

“Dünya Ekonomik Durumu ve Beklentileri” adlı 2019 Birleşmiş Milletler raporunda ülkeler iktisadi açıdan; gelişmiş ekonomiler (Developed economies), geçiş ekonomileri (Economies in transition) ve gelişmekte olan ekonomiler (Developing economies) olarak üç grupta sinıflandırılmaktadır (United Nations, 2019: s.167). Ancak bu sinıflandırmada aynı grupta yer alan ülkeler arasında; özgürlük, demokrasi ve sosyal gelişmişlik bakımından birçok farklılık bulunmaktadır. Söz konusu faktörlere atfedilen farklı önem seviyelerine göre alternatif sınıflandırmalar da yapılabilmektedir. Özellikle, Birleşmiş Milletler'in sınıflandırmasında gelişmekte olan ülkeler olarak kategorize edilen ülkelere yönelik birçok teorik yaklaşımın farklı sınıflandırmaları mevcuttur. "Az Gelişmiş Ülkeler”, "Geri Kalmış Ülkeler" ve "Çevre Ülkeler" bunlardan bazılarıdır. Bu sınıflandırmaların tümünde; Ortadoğu, Afrika, Güney Asya ve Latin Amerika gibi benzer coğrafi bölgelerden ülkeler yer almaktadir (Er, 1997: s.294).

Gelişmekte olan ülkeler; kırılgan ekonomilere sahip olmaları, gelişmiş ülkelere nazaran sosyal gerginliklere, askeri ve politik çatışmalara daha çok sahne olmaları bakımından demokratikleşme konusunda tartışmalı bir grubu oluşturmaktadır. Söz konusu ülkelerdeki demokrasi ve özgürlük seviyeleri genellikle gelişmiş ülkelere göre daha düşüktür. Bu farklılığın hem ekonomik ve politik hem de ulusal ve ulus-aşırı olarak ayrıştırılabilecek birçok nedeni bulunmaktadır. Bu nedenlerin açıkça ortaya konabilmesi için gelişmekte olan ülkelere yönelik yapılacak çalışmalar büyük önem taşımaktadır.

Bu çalışmada, ekonomik kalkınma ve devletin ekonomideki büyüklügü gibi iki ulusal etkenin yanı sıra ulus-aşırı bir etken olan küreselleşmenin demokratikleşme seviyesi üzerindeki etkisi araştırılmaktadır. Çalışmada ülke grubu olarak; kalkınma ekonomisi literatüründe gelişmekte olan ülkeler sınıflandırması altındaki daha spesifik bir grubu oluşturan "Yeni Sanayileşen Ülkeler" ele alınmaktadır. Bu ülke grubunun tercih edilmesinde küreselleşme sürecinin önemli bir payı bulunmaktadır. Zira gelişmekte olan ülkeler, finansal serbestleşmenin de getirileri sayesinde 1990'lar sonrası küreselleşme sürecinin en önemli kazananları olarak değerlendirilmiştir. Ancak son dönemde bu ülkelerin küreselleşmeden olumsuz etkilenmeye başladığına dair görüşler literatürde sıkça yer almaya başlamıştır. Bu gelişmelere koşut olarak, özellikle gelişmekte olan Asya ülkelerinin Batı merkezli uluslararası ekonomik sistem ile olan ilişkilerinin gelecekte nasıl şekilleneceği tartışması öne çıkmaktadır. Zira Batı sistemine alternatif olarak giderek sayıları artan Asya merkezli finansal kurumlar ve farklı coğrafyalarda genişleyen Çin etkisi, uluslararası sistemde önemli değişikliklerin yaşanabileceğine dair görüşleri beraberinde getirmektedir.

Öte yandan, Çin'in ne liberal kapitalizme ne de ithal ikameciliğe tam anlamıyla benzemeyen yeni bir otoriter devlet kapitalizmi modeli uyguladığına ve buna mukabil hem uluslararası yatırımları dışlamayan hem de sınırsız bir serbestleşmeyi kabul etmeyen bir küreselleşme (seçici/selektif küreselleşme) yaklaşımı benimsediğine dair görüşler söz konusudur (Kutlay ve Öniş, 2020: s.44). Çin'deki bu politikaların başta Asya ülkeleri olmak üzere diğer gelişmekte olan ülkelerce yeni bir yol olarak değerlendirilip değerlendirilmeyeceği henüz bilinmemektedir. Yine de küreselleşme ve devletin ekonomideki büyüklüğü gibi değişkenlerin bu ülkelerin demokratik yapıları üzerindeki etkilerinin analiz edilmesi, gelecek için tahminlerde bulunmaya katkı sağlayabilir. Bu nedenlerle, çalışmada Asya ülkelerinin çoğunlukta olduğu ancak dünyanın farklı bölgelerinden gelişmekte olan ekonomileri de kapsayan yeni sanayileşen ülkeler grubu tercih edilmiştir. 
Bu çalışmanın amacı; yeni sanayileşen ülkelerde küreselleşme, ekonomik kalkınma ve kamu kesimi büyüklüğünün demokratikleşme üzerine etkisi panel veri analizi yöntemiyle 20032017 dönemi yıllık veriler kullanılarak analiz etmektir. Beş bölümden oluşan çalışmanın birinci bölümde giriş, ikinci bölümde teorik çerçeve, üçüncü bölümünde literatür özeti, dördüncü bölümde ekonometrik analiz ve son bölümde ise sonuç yer almaktadır.

\section{Teorik Çerçeve}

Çalışmada yer alan bağımsız değişkenlerden ilki, küreselleşme düzeyidir. Küreselleşme kısaca, küresel ölçekteki toplumsal karşılıklı bağımlılıkları ve mübadeleleri oluşturan, artıran, yaygınlaştıran ve yoğunlaştıran sosyal süreçlerin çok boyutlu kümesi olarak tanımlanabilir. Çok boyutlu olması nedeniyle küreselleşmenin etkileri ülkelerin özelliklerine göre farklılıklar göstermektedir (Steger, 2013: s.31-32). Birçok bakımdan olumlu ve olumsuz etkileri bir arada bulunması nedeniyle günümüzde küreselleşmeye yönelik farklı yaklaşımlardan söz edilebilmektedir. Bunlar temelde "aşırı küreselleşmeciler" (hyperglobalist), "kuşkucular" yani küreselleşme karşıtları (skeptical) ve "dönüşümcüler" (transformationalist) olarak 3 grupta siniflandırılmaktadır (Held, McGrew, Goldblatt \& Perraton, 1999: s.3-10).

Küreselleşmeyi destekleyen görüşler; demokrasi, insan hakları, özgürlük ve doğanın korunması gibi değerlerin küreselleşme sayesinde evrensel hale geldiğini savunmaktadır (Kıvılcım, 2013: s.226). Diğer taraftan küreselleşme karşıtları ise küreselleşmenin kültürler, uygarlıklar veya bölgeler arasında yeni çatışmaları beraberinde getireceğini; evrensel değerler üzerine kurulu küresel bir uygarlıktan ziyade radikalizmin ve saldırgan milliyetçiliğin yükselmesine sebep olacağını öngörmektedir (Bozkurt, 2020: s.12). Bu bakımdan küresel entegrasyonun ülkelerin demokratikleşme seviyeleri üzerinde farklı etkiler ortaya çıkacağını öngören görüşlerin bulunduğu ifade edilebilir.

Çalışmadaki diğer bir bağımsız değişken olan ekonomik kalkınmanın toplumsal kutuplaşma ve politik radikalizm gibi çatışmacı olguları azaltması ve böylece ülkelerin demokratikleşme seviyeleri üzerinde olumlu bir etkiye sahip olması beklenmektedir. Son olarak devletin ekonomideki ağırlığının demokrasi üzerindeki etkisinin ise liberal ve korumacı ekonomik yaklaşımlara göre farklı sonuçlar ortaya çıkaracağı tahmin edilmektedir. Liberal bakış açısına göre ekonomide devlet faaliyetlerinin artmasının bir yandan özel sektöre yönelik bir dışlama etkisini beraberinde getirmesi sonucu ekonomik özgürlüğün azalacağı; öte yandan artan ekonomik faaliyetleri sayesinde devletin daha güçlü bir otorite olarak politik özgürlüğü kısıtlayacağı öngörülmektedir. Korumacı ekonomik yaklaşımlara göre ise ekonomide artan devlet ağırlı̆̆ının; sanayileşme ve kalkınmayı artıracağı ve böylece ulusal refah ve özgürlükler üzerinde olumlu bir etkide bulunacağı beklenmektedir.

$\mathrm{Bu}$ çalışmada kalkınma ekonomisinde gelişmekte olan ülkeler sınıflandırmasının bir alt grubu olarak yer alan "Yeni Sanayileşen Ülkeler" grubu ele alınmaktadır. Yeni sanayileşen ülkelerin sinıflandırılması konusunda iktisatçılar ve siyaset bilimciler arasında ortak bir görüş bulunmamaktadır. Ancak genel anlamda bir ülkenin yeni sanayileşen olarak sınıflandırılabilmesi için gayri safi yurtiçi hasılasındaki kayda değer oranda büyüme, kişi başına düşen gelir ve yaşam standardındaki artışlar temel kriterler olarak değerlendirilmektedir. Bunun yanı sıra düşük yolsuzluk seviyesi ve siyasal istikrar gibi sosyo-politik faktörler de bu sinıflandırmaya dahil edilebilmektedir (Majaski, t.y.). Bazı iktisatçların sınıflandırmalarında ise iki temel ölçüt öne çıkmaktadır: Bunlardan ilki, söz 
konusu ülkenin ihracata yönelik sanayileşme stratejisini benimsemiş olması ve imalat sanayinin gayri safi yurtiçi hasıla içindeki payının en az yüzde 20-25 düzeyine ulaşmasıdır (Weiss, 1988). Baz alınan kriterlerdeki çeşitlilik nedeniyle yeni sanayileşen olarak sınıflandırılan ülkelerin sayısı, dönemsel olarak farklılık arz etmektedir. Örneğin, ilk olarak; 1970'lerden 1980'lerin sonuna kadar Hong Kong, Güney Kore, Singapur ve Tayvan bu grupta yer almıştır. Ardından, 2000'lere doğru ise Çin, Brezilya, Hindistan, Meksika, Güney Afrika, Türkiye, Malezya, Filipinler ve Tayland yeni sanayileşen ülkeler olarak sınıflandırılmaya başlanmıştır (Majaski, t.y.).

Zaman içinde ülke sayısındaki değişimler ve sınıflandırma kriterlerindeki çeşitlilik nedeniyle literatürde farklı ülke kümelerinin yeni sanayileşen olarak değerlendirildiği çalışmaların olduğu görülmektedir. Örneğin: Zhang, Liu ve Bae (2017), Ghazali ve Ali (2019), Kılıç (2020) ile Shahzad, Doğan, Sinha ve Fareed (2020) çalışmalarında Brezilya, Çin, Hindistan, Endonezya, Malezya, Meksika, Filipinler, Güney Afrika, Tayland ve Türkiye'yi içeren toplam 10 ülkeyi yeni sanayileşen ülkeler sınıfına dahil etmiştir. Hossain (2011) ise bu ülkelerden Endonezya hariç 9 ülkeyi baz almıştır. Diğer taraftan Destek (2016); Brezilya, Hindistan, Türkiye, Güney Afrika, Meksika ve Malezya olmak üzere toplam 6 ülkeyi yeni sanayileşen kategorisinde ele almıştır. Zeren ve Koç (2014) ise çalışmalarına; IMF'nin tanımlamasını baz alarak Hindistan, Malezya, Meksika, Güney Afrika, Filipinler, Tayland ve Türkiye'yi içerecek şekilde 7 ülkeyi dahil etmişlerdir. Bu çalışmada, daha yakın tarihli çalışmalarda olduğu gibi 10 ülkeyi kapsayan bir sınıflandırma tercih edilmiştir.

\section{Literatür Özeti}

Mevcut demokratikleşme literatürü oldukça geniştir. Bu alandaki çalışmalar, genellikle bağımsız değişken olarak ele alınan demokrasinin ekonomik küreselleşme üzerindeki etkilerinin sınanması üzerinedir. Garrett (2000), demokratikleşmenin ekonomik küreselleşmeyi artırdığına dair önermelerin daimi bir geçerliliği olmadığını, demokratikleşmenin karakterini oluşturan gruplara göre değişiklik gösterdiğini ortaya koymaktadır. Ancak genel anlamda dışa açıklık karşıtı bir görüşü temsil etmiyorsa demokratikleşmenin küreselleşmeyi artıracağına vurgu yapmaktadır. Dutt ve Mitra (2002) da benzer şekilde, demokrasilerin baskıcı otoritelere göre ekonomik küreselleşmeyi artırma konusunda daha etkili olacağını öne sürmektedir. Quinn (2003), geniş bir tarihsel perspektifte bakıldığında demokratikleşmenin finansal küreselleşme üzerindeki olumlu etkisinin Birinci Dünya Savaşı sonrası süreçte oluşmaya başladığı, önceki süreçte ise negatif bir etkisinin söz konusu olduğu sonucuna varmaktadır. Milner ve Kubota (2005), politik alandaki demokratikleşmenin hükümetleri ticari engeller uygulamaktan alıkoyacağını öne sürerek; bu argümanı 1970-1999 döneminde özellikle emek zengini gelişmekte olan ülkelerde ampirik olarak desteklemektedirler. Bu bakımdan demokratikleşmenin küreselleşmeyi teşvik ettiğini tespit etmektedirler. Benzer şekilde O'Rourke ve Taylor (2006) da emek faktörü açısından zengin olan ülkelerde demokratikleşme sürecinde işçiler için ticaretin faydalarının görünür hale geleceğini ve bu durumun söz konusu ülkelerde daha liberal ve ekonomik anlamda küreselleşmeyi destekleyecek politikaların uygulanmasının önünü açacağını savunmaktadır. Brune'e göre de politik özgürleşme ve demokrasi, gelişmekte olan ülkeleri finansal serbestleşme ve dolaylı olarak küreselleşme konusunda teşvik etmektedir (Brune, Garrett, Guisinger \& Sorens, 2001).

Son dönemlerde demokratikleşme ve küreselleşme arasındaki ilişkiye yönelik çalışmalarda nedenselliğin yönü küreselleşmenin demokrasi üzerindeki etkisini sınayacak şekilde 
değişmeye başlamıştır. Ekonomik küreselleşme ve ticari açıklığın daha fazla demokrasiyi ve ekonomik kalkınmayı teşvik edeceğini öne süren yaklaşımların sayısı giderek artmaktadır (bkz. Held, 1995; Falk, 1999; Hardt ve Negri, 2001; Boix ve Garicano, 2001; Adsera ve Boix, 2002; Boix, 2003; Erdağ ve Peker, 2014; Doğan, 2005; Acemoğlu ve Robinson, 2016). Literatürde bu yaklaşımları destekleyen birçok ampirik çalışma bulunmaktadır. Örneğin: Rudra (2005), 1927-1997 dönemi için 59 gelişmekte olan ülke verisini kapsayan çalışmasında, ihracattaki artışın ve küresel sisteme entegrasyonun demokratik gelişmelere zemin hazırlayacağını savunmaktadır. Aynı şekilde Doces (2006) de ihracattaki artışın demokratikleşme seviyesini artıracağını desteklemektedir. Tarihsel boyutu daha geniş olan üç çalışmada ise; Eichengreen ve Leblang (2007), küreselleşmenin İkinci Dünya Savaşı sonrası demokratikleşmeyi önemli düzeyde artıran başat olgulardan biri olduğunu; LópezCórdova ve Meissner (2005), finansal açılığın demokrasi üzerindeki olumlu etkisinin 1895'ten itibaren açıç̧a görüldügüün̈; Boix (2011) ise 19. yüzyılın başından 20. yüzyılın sonuna kadarki dönemde ekonomik büyüme ve kalkınmanın demokratikleşmeyi önemli derecede olumlu etkilediğini ifade etmektedir.

Literatürde küreselleşmenin demokratikleşmeyi olumlu yönde etkilediğine dair görüşe kuşkulu yaklaşanlar da bulunmaktadır (bkz. Barnet ve Cavanagh, 1995; Hirst ve Thompson, 1998; Gray, 1999; Şahin, 2006). Bazı çalışmalar, bu yaklaşımları farklı açılardan ampirik olarak desteklemektedir. Örneğin: Decker ve Lim'in (2009), 1948-1999 dönemini kapsayan çalışmalarında uluslararası ticaretteki artışın genel anlamda demokratikleşme üzerinde olumlu bir etkisinin bulunduğu kabul edilirken; bu etkinin gelişmiş ve gelişmekte olan ülkelere göre değişiklik gösterdiği belirtilmektedir. Benzer şekilde Milner ve Mukharjee (2009) de gelişmekte olan ülkelerde ekonomik küreselleşmenin demokrasiyi artırıcı etkisinin zayıf olduğu sonucuna varmaktadır. Kollias ve Paleologou (2016) 1970-2011 dönemi için, De Macedo, Pereira, Martins, ve Jalles (2013) ise 1970-2005 dönemi için küreselleşmenin çeşitli gelir gruplarındaki ülkelerin demokratikleşme seviyeleri üzerindeki etkisinin farklılık arz ettiğini ancak genel anlamda olumlu bir etkinin söz konusu olduğunu ortaya koymaktadırlar. Bunların yanı sıra Li ve Reuveny (2003) ile Rigobon ve Rodrik (2005), ticari açıklığın demokratikleşme üzerinde olumsuz etkileri olduğu sonucuna varmaktadır. Daha dar kapsamlı bir çalışmada (Acaravcı ve Erdoğan, 2015) ise Türkiye için dışa açıklık düzeyindeki artışın uzun dönemde demokratikleşmeyi azalttığı belirtilmektedir.

Robinson (2006) ile Acemoglu, Johnson, Robinson \& Yared (2008), demokrasi ve kişi başına düşen gelir arasında güçlü bir nedensellik ilişkisinin söz konusu olduğunu ancak ekonomik kalkınmayı demokrasinin temel belirleyicisi olarak değerlendiren hakim görüşün aksine bu ilişkinin demokrasiden gelire doğru olduğunu öne sürmektedir. Buna koşut olarak, demokrasinin ekonomik kalkınmayı artırdığı doğrulanırken; kalkınmanın demokrasi üzerinde etkili olduğuna dair yeterince bulguya rastlanmadığı belirtilmektedir.

Bu çalışmada bağımsız değişken olarak kullanılan ekonomideki kamu kesimi büyüklüğünü demokratikleşme gibi ekonomi dışı faktörlerle ilişkilendiren ampirik çalışmalar literatürde oldukça sınırlıdır. Kamu kesimi büyüklügünün dahil edildiği çalışmalarda genellikle bu değişkenin ekonomik büyüme ile olan ilişkisine odaklanılmaktadır. Ancak kamu kesimi büyüklüğü ile demokratikleşme arasındaki ilişkiyi belirlemeye yönelik yapılan bir çalışmada (Zortuk ve Beşer, 2014), geçiş ekonomilerinde dışa açıklık ve demokratik yapıdan kamu kesimi büyüklüğüne doğru pozitif yönde bir nedensellik tespit edilmiştir. 


\section{Ekonometrik Analiz}

\section{Veri Seti}

Bu çalışma; Brezilya, Çin, Hindistan, Endonezya, Malezya, Meksika, Filipinler, Güney Afrika, Tayland ve Türkiye'yi içeren yeni sanayileşen ülkeleri kapsamaktadır. Çalışmada bu ülkelere ilişkin 2003-2017 yılları arasındaki veriler, EViews 9 ve Stata 15.0 programları kullanılarak analiz edilmiştir. Çalışmada bağımlı değişken olarak demokratikleşme endeksi; bağımsız değişken olarak ise küreselleşme endeksi, kişi başına düşen milli gelir ve kamu kesimi nihai tüketim harcamalarının gayrisafi yurtiçi hasıla içindeki payı alınmıştır.

Çalışmada demokratikleşme değişkeni olarak alınan Freedom House Endeksi; puanlar, derecelendirmeler ve mevcut durum olmak üzere üç temel unsur baz alınarak oluşturulmakta ve 195 ülke ile 14 bölgeyi kapsamaktadır. Endeks oluşturulurken her ülke veya bölge için 10 siyasi hak ve 15 sivil özgürlük göstergesi kullanılmakta; siyasi haklar için en yüksek 40, sivil özgürlükler için ise en yüksek 60 puan verilmektedir. Böylece her ülke veya bölge için 0 ila 100 arasında bir puan belirlenmektedir. Siyasi haklar; seçim süreci, politik çoğulculuk-politik katılım ve hükümet işlevleri olmak üzere 3 alt başlığa ayrılmaktadır. Sivil özgürlükler ise; ifade ve inanç özgürlüğü, dernek kurma hakkı ve örgütsel haklar, hukukun üstünlüğü ve son olarak kişisel özerklik ve bireysel hakları kapsayan dört alt kategoriden oluşmaktadır. Bu kategorilere göre elde edilen puanlar, 1,0-7,0 arası bir değere indirgenerek ülke ve bölgelere özgürlük dereceleri verilmektedir. Bunlar; özgür (1,0 ile 2,5), k1smen özgür $(3,0$ ile 2,5) ve özgür değil (5.5 ile 7.0) olarak değerlendirilmektedir (Freedom House, 2020). Bu çalışmada tüm kategoriler için ülkelerin toplam puanları kullanılmıştır.

Küreselleşme sürecinin ekonomik, kültürel, hukuki, sosyolojik, politik vb. boyutlarının olması, ülkelerin küreselleşme düzeylerinin ölçülmesinde de çok kapsamlı bir araştırmayı gerekli kılmaktadır. Bu nedenle literatürde küreselleşmenin farklı bileşenlerini içeren çeşitli endeksler bulunmaktadır. Bunlardan bazıları: 2001 KFP (A.T. Kearney/Foreign Policy Globalization Index) Küreselleşme Endeksi; 2002 KOF (KOF Swiss Economic Institute Globalization Index) Küreselleşme Endeksi, 2004 CSGR (The Centre for the Study of Globalisation and Regionalisation) Küreselleşme Endeksi, 2008 MGI (The Maastricht Globalisation Index), 2010 NGI (New Globalization Index)'dır (Topuz, 2016: s.787). Aşağıdaki Tablo 1'de bu endekslerin kapsadıkları konu başlıkları yer almaktadır.

Tablo 1. Küreselleşme Endekslerinin Kapsamı

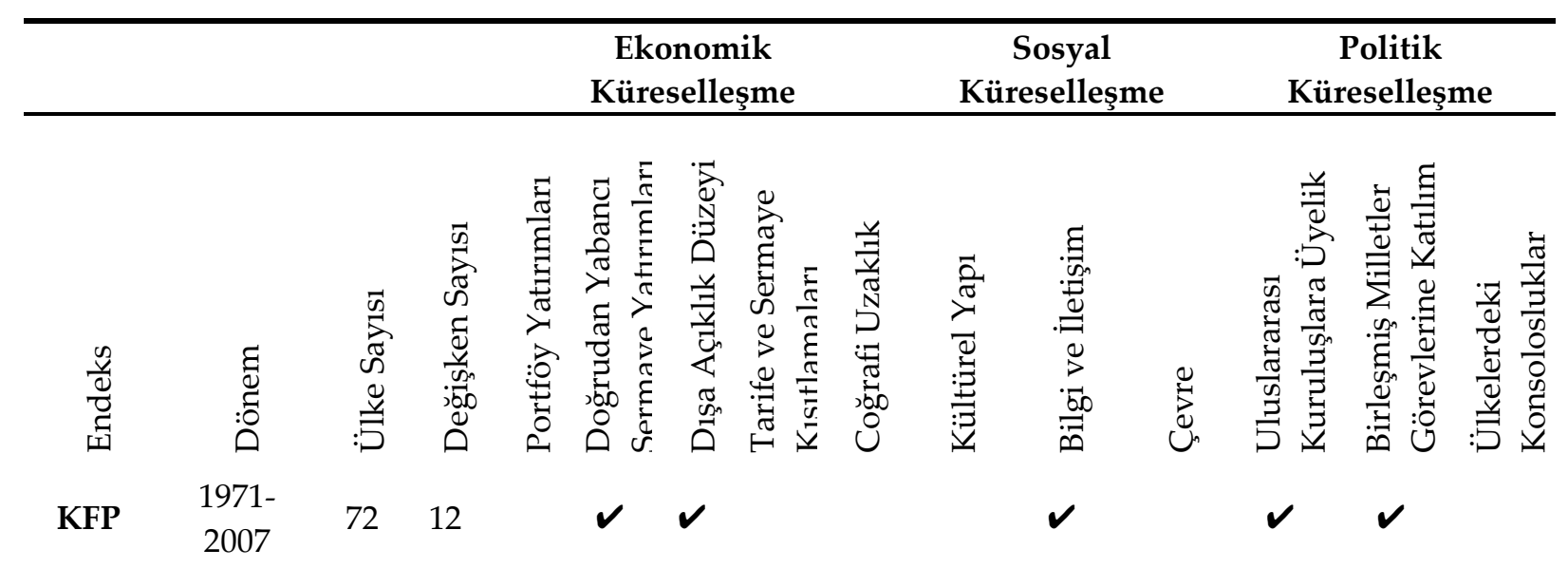




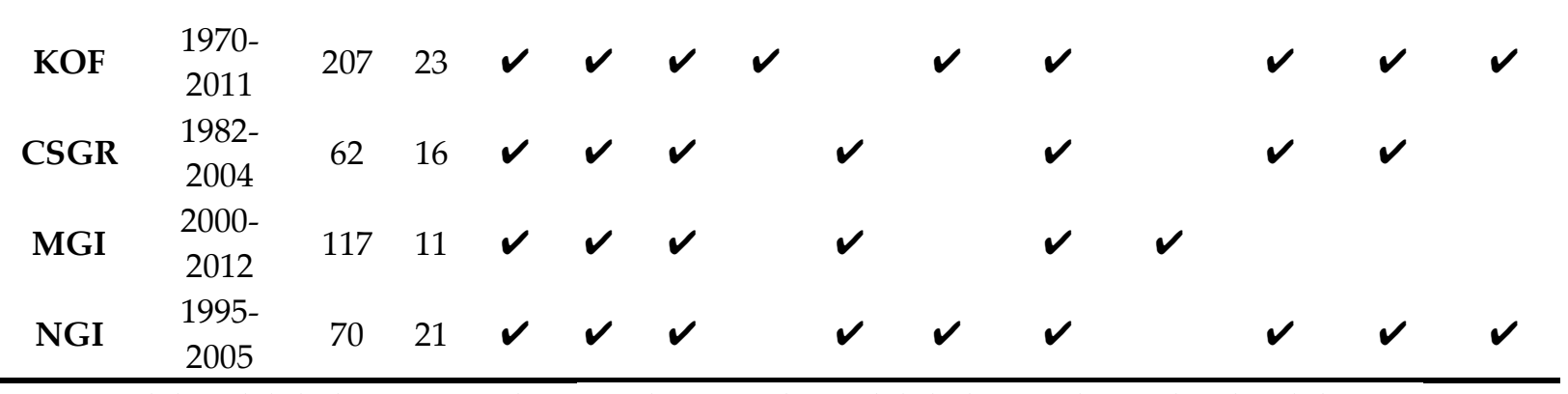

Not: Endekse dahil olan göstergeler " $\boldsymbol{V}$ " ile gösterilmiş, dahil olmayanlar ise boş bırakılmıştır.

Kaynak: (Hayaloğlu, Kalaycı, \& Artan, 2015: s.123).

NGI ve KOF; küreselleşmenin ekonomik, sosyal ve politik yönlerini temsil etmek üzere seçilen alt kriterleri en fazla sayıda endekslerdir. Ancak; dönem, ülke ve değişken sayısı göz önüne alındığında küreselleşme endeksleri arasında en kapsamlısının KOF endeksi olduğu görülmektedir. Bu nedenle çalışmada ülkelerin küreselleşme seviyesini temsilen KOF İsviçre Ekonomi Araştırmaları Enstitüsü'nün KOF endeksi kullanılmıştır (KOF Globalisation Index, 2020).

Ekonometrik analizde kullanılacak bağımlı ve bağımsız değişkenlere ilişkin bilgiler Tablo 2'de yer almaktadir.

Tablo 2. Veri Seti

\begin{tabular}{|c|c|c|c|c|c|}
\hline Değişken & Sembol & Açıklama & Birim & Kaynak & $\begin{array}{c}\text { Referans Alınan } \\
\text { Çalışmalar }\end{array}$ \\
\hline Demokratikleşme & FRE & $\begin{array}{l}\text { Freedom House } \\
\text { Endeksi }\end{array}$ & Oran & $\begin{array}{l}\text { Freedom } \\
\text { House }\end{array}$ & $\begin{array}{c}\text { (Papaioannou ve } \\
\text { Siourounıs, 2008; } \\
\text { Bayar ve Alakbarov, } \\
\text { 2016; Polterovich ve } \\
\text { Popov, 2005; } \\
\text { Hayaloğlu vd., 2015; } \\
\text { Kollias ve } \\
\text { Paleologou, 2016) } \\
\text { (Topuz, 2016; }\end{array}$ \\
\hline $\begin{array}{l}\text { Küreselleşme } \\
\text { Düzeyi }\end{array}$ & $\mathrm{KOF}$ & KOF Endeksi & Oran & $\begin{array}{l}\text { KOF İsviçre } \\
\text { Ekonomi } \\
\text { Araştırmaları } \\
\text { Enstitüsü }\end{array}$ & $\begin{array}{l}\text { Macedo vd., 2013; } \\
\text { Gurgul ve Lach, } \\
\text { 2014; Villaverde ve } \\
\text { Maza, 2011; Olimpia } \\
\text { ve Stela, 2017) }\end{array}$ \\
\hline $\begin{array}{l}\text { Ekonomik } \\
\text { Kalkınma }\end{array}$ & GDP & $\begin{array}{c}\text { Kişi Başına } \\
\text { Düşen Milli Gelir }\end{array}$ & Logaritmik & Dünya Bankası & $\begin{array}{l}\text { (Uddin, 2015; Verter } \\
\text { ve Osakwe, 2015; } \\
\text { Doces, 2006; Eren ve } \\
\text { Çütcü, 2018; Linden } \\
\text { ve Ray, 2017) }\end{array}$ \\
\hline $\begin{array}{l}\text { Kamu Kesimi } \\
\text { Büyüklüğü }\end{array}$ & GOV & $\begin{array}{l}\text { Kamu Kesimi } \\
\text { Toplam Nihai } \\
\text { Tüketim } \\
\text { Harcamalarının } \\
\text { Gayri Safi Yurtiçi } \\
\text { Hasıla İçindeki }\end{array}$ & Oran & Dünya Bankası & $\begin{array}{c}\text { (Landau, 1983; } \\
\text { Alesina ve } \\
\text { Wacziarg, 1998; } \\
\text { Fölster ve } \\
\text { Henrekson, 2001; } \\
\text { Loizides ve }\end{array}$ \\
\hline
\end{tabular}




\section{Model}

$\mathrm{Bu}$ çalışmadaki beklenti; küreselleşme, ekonomik kalkınma ve ekonomik kalkınmanın demokratikleşmeyi pozitif yönde etkileyeceği yönündedir. Ekonomideki kamu kesimi büyüklüğünün ise özel sektörü dışlama etkisi nedeniyle ekonomik teşebbüs özgürlügünü sınırlayacağı ve dolayısıyla demokratikleşmeyi negatif yönde etkileyeceği beklenmektedir. $\mathrm{Bu}$ bağlamda küresel entegrasyon, ekonomik kalkınma ve kamu kesimi büyüklügünün demokratikleşme seviyesi üzerindekini etkisini ortaya koyabilmek adına aşağıda yer alan model tahmin edilmiştir.

$\mathrm{FRE}_{i t}=\beta_{0}+\beta_{1} \mathrm{KOF}_{i t}+\beta_{2} \mathrm{GDP}_{i t}+\beta_{3} \mathrm{GOV}_{i t}+u_{i t}$

Denklem 1'deki modelde i; çalışmanın yatay kesit birimlerini (ülkeleri), $t$ ise zaman boyutunu ifade etmektedir.

\section{Yöntem ve Ampirik Bulgular}

Bu çalışmada yeni sanayileşen ülkelerde küreselleşme, ekonomik kalkınma ve ekonomideki kamu kesimi büyüklüğünün demokratikleşme üzerine etkisi 2003-2017 dönemi y1llık veriler kullanılarak panel veri analizi yöntemi ile araştırılmıştır.

Panel veri modelleri parametrelerin birim ve/veya zamana göre değer almasına bağlı olarak sınıflandırılabilir. Hem sabit hem de eğim katsayılarının sabit olduğu panel veri modeli Denklem 2'de verilmiştir.

$\mathrm{Y}_{i t}=\propto+\mathrm{X}^{\prime}{ }_{i t} \beta+u_{i t}$

denklemindeki Y bağımlı değişkeni, $\propto$ sabit terimi, $X^{\prime}$ bağımsız değişkeni, $\beta$ bağımsız değişkenin katsayısını ve $u$ hata terimini göstermektedir. Burada hata terimi $\left(u_{i t}\right)$ zaman etkileri ve bireysel etkiler yönünden bileşenlerine ayrıştırılması temeline dayanır. Hata terimi çözümlenirse:

$\mathrm{u}_{i t}=\mathrm{u}_{i}+\lambda_{t}+\vartheta_{i t}$

denklemi elde edilmektedir. Bu son eşitliğe hata bileşenleri modeli denir. Eşitlikte yer alan $u_{i}$ bireysel etkileri, $\lambda_{t}$ ise zaman etkilerini ifade etmektedir. Burada $\mathrm{u}_{i t} ; \lambda_{t}$ ve $\vartheta_{i t} \sim \operatorname{IID}(0, \sigma 2)$ hata terimlerinin ortalamasının 0 , varyansının sabit olduğu ve normal dağıldığı varsayılmaktadır (Gujarati, 1999; Baltagi, 2001).

Panel veri analizinde seriler arasındaki ilişkiyi analiz etmede öncelikle yatay kesit bağımlılı̆̆ testi yapılır. Bu testte bireysel ve zaman etkilerinin türü tanımlanır. Modelde yer alan değişkenler arasında herhangi bir ilişkinin var olup olmadığı içsellik sınaması ile tespit edilir. Son aşamada ise model tahmin edilip; söz konusu modelde otokorelasyon ve değişen varyans sorunlarının varlığı incelenir (Dam ve Yıldız, 2016: s.229).

$\mathrm{Bu}$ çalışmada ilk olarak, yatay kesit bağımlılığını sınamak için Frees (1995) testi uygulanmıştır. Ardından serilerin durağanlığı için Pesaran (2007) tarafından geliştirilen CIPS panel birim kök testi, değişen varyans için Levene (1960), Brown ve Forsythe (1974) testi, otokorelasyon için Bhargava, Franzini ve Narendranathan (1982)'ın Durbin-Watson testi uygulanmıştır. Tahmin yönteminin belirlenmesi için Breusch-Pagan LM testi ve Hausman 
(1978) testi yapılmıştır. Seriler arasındaki ilişki Driscoll ve Kraay (1998) standart hatalar yöntemi ile tahmin edilmiş ve son olarak seriler arasındaki nedensellik ilişkisi DumitrescueHurlin Panel Nedensellik Testi ile sınanmıştır. Çalışmada modele alınan verilere ilişkin özet istatistikler Tablo 3'te belirtilmiştir.

Tablo 3. Yeni Sanayileşen Ülkelerde Tanımlayıcı İstatistikler ve Korelasyon Matrisi

\begin{tabular}{lcccc}
\hline & FRE & KOF & GDP & GOV \\
\hline Ortalama & 60.960 & 66.002 & 4.955 & 13.685 \\
Medyan & 65.000 & 65.056 & 4.759 & 13.068 \\
Maksimum & 88.000 & 81.408 & 7.711 & 20.799 \\
Minimum & 13.000 & 52.192 & 3.850 & 8.110 \\
Standart Hata & 19.585 & 6.118 & 0.892 & 3.632 \\
FRE & 1.000 & & & \\
KOF & -0.251 & 1.000 & & \\
GDP & 0.083 & -0.117 & 1.000 & 1.000 \\
GOV & 0.048 & 0.062 & -0.489 & 150 \\
Gözlem & 150 & 150 & 150 & \\
\hline
\end{tabular}

Tablo 3'te, değişkenlere ait tanımlayıcı istatistikler verilmiştir. Çalışmaya dahil edilen değişkenlere ait ortalama, medyan, maksimum, minimum, standart sapma, korelasyon katsayıları ve diğer tanımlayıcı istatistikler bu tabloda gösterilmiştir. Korelasyon analizi sonuçlarına bakıldığında ise FRE değişkeni ile KOF değişkeni arasında negatif yönlü korelasyon olduğunu göstermektedir. FRE ile GDP arasında pozitif yönlü güçlü bir ilişki olduğu; FRE ile GOV arasında pozitif yönlü fakat zayıf bir ilişkinin bulunduğu tespit edilmiştir.

\section{Yatay Kesit Bă̆ımlılı̆̆ı Testi}

Seriler arasında yatay kesit bağımlılığı varken, bu durum dikkate alınmadan analiz yapılması elde edilecek sonuçları önemli ölçüde sapmalı yapacaktır (Pesaran, 2021). Bu nedenle analize başlamadan önce, serilerde ve eş-bütünleşme denkleminde yatay kesit bağımlılığının varlığının test edilmesi gerekmektedir. Yatay kesit bağımlılığının yapılacak birim kök ve eş-bütünleşme testleri seçilirken göz önünde bulundurulmaması; yapılan analizin sonuçlarını sapmalı ve tutarsız hale getirebilecektir (Altıntaş ve Mercan, 2015).

Çalışmada seriler arasında yatay kesit bağımlılığının olup olmadığı Frees (1995) testi ile analiz edilmiştir. Frees testi rank korelasyon katsayılarının kareleri toplamına dayanmaktadır (Yerdelen Tatoğlu, 2020: s.247-248). Frees test istatistiği:

$$
F R E=N\left(R_{A V E}^{2}-(T-1)^{-1}\right.
$$

şeklinde ifade edilmektedir. Denklem $4^{\prime}$ teki $\mathrm{N}$ ülkeleri, T serilerin zaman boyutunu ve $R_{A V E}^{2}$ ortalama determinant katsayısını göstermektedir. Denklemde yer alan $R_{A V E}^{2}$ değeri: 


$$
R_{A V E}^{2}=\left[\frac{2}{N(N-1)}\right]^{2} \sum_{i=1}^{N-1} \sum_{j=i+1}^{N} \check{\mathrm{r}}_{i j \cong \frac{2}{N(N-1)}}^{2} \sum_{i=1}^{N-1} \sum_{j=i+1}^{N} \check{\mathrm{r}}_{i j}^{2}
$$

biçiminde elde edilmektedir. Burada $\frac{2}{N(N-1)}$ ve $\left[\frac{2}{N(N-1)}\right]^{2}$ arasındaki fark küçük olduğu için bunun yerine $\frac{2}{N(N-1)}$ kullanılabilir. Frees test istatistiğinde asimptotik $\mathrm{Q}$ dağılımında $\mathrm{N}$ sonsuz ve $\mathrm{T}$ sabit olduğu varsayılır. Burada eğer $R_{A V E}^{2}$ değeri $(T-1)^{-1}+\frac{Q_{q}}{N}$ değerinden büyük ise boş hipotez reddedilir. Burada $Q_{q} ; \mathrm{Q}$ dağılımındaki kantili ifade etmektedir. Frees test istatistiğinde $Q$ dağılım için kritik değerler,

$Q=a(T)\left(X_{1, T-1}^{2}-(T-1)\right)+b(T)\left(X_{2, \frac{T(T-3)}{2}}^{2}-T(T-3) / 2\right.$

Denklem 6'dan hareketle hesaplanmaktadır. Serbestlik dereceleri; $X_{1, T-1}^{2} ;(T-1)$ ve $X_{2, \frac{T(T-3)}{2}}^{2}$; $\left[\frac{T(T-3)}{2}\right]$ olan ve $\chi^{2}$ dağılımına uygun bağımsız rassal değişkenlerdir. Ayrıca $a(T)$ ve $b(T)$ değerleri;

$a(T)=4(T+2) /\left(5(T-1)^{2}(T+1)\right)$

ve

$b(T)=2(5 T+6) /(5 T(T-1)(T+1))$

eşitlikleri yardımıyla hesaplanmaktadır. $R_{A V E}^{2}>(T-1)^{2}+\frac{Q_{q}}{N}$ olduğu durumda $\mathrm{H}_{0}$ hipotezi reddedilir. $\mathrm{Q}_{q}$; $\mathrm{Q}$ dağılımının q. kantilidir. $\mathrm{Bu}$ sebeple $\mathrm{Q}$ dağılımı, $\chi^{2}$ dağılan iki rassal değişkenin toplamına eşittir ve bunun değeri ise $T^{\prime}$ ye bağlıdır. Asimptotik nitelikleri bakımında Frees testi, Pesaran'ın CD testiyle aynıdır.

Bu teste ilişkin sonuçlar Tablo 4'te belirtilmiştir.

Tablo 4. Yatay Kesit Bağımlılık Test Sonuçları

\begin{tabular}{ll}
\hline Test & Yeni Sanayileşen Ülkeler \\
\hline Frees & $1.515^{* * *}$ \\
\hline
\end{tabular}

Not: ${ }^{* * *} \% 1$ anlamlılık düzeyini temsil etmektedir. Bu testte elde edilen test istatistiği, kritik değerler (\%10; 0.719, \%5; 0.2262 ve \%1; 0.3351) ile mukayese edilir.

Tablo 4'teki sonuçlara göre Frees test istatistiği sonucu verilen kritik değerlerden büyük olduğu için "Yatay kesit bağımlılığ yoktur" biçiminde yokluk hipotezi reddedilmektedir. Bu durumda \%1 anlamlılık düzeyinde yatay kesit bağımlılığ kesit bağımlılı̆̆1 sorununun varlığı durumunda birinci kuşak birim kök testlerinin güvenilir olmadığı ikinci kuşak birim kök testlerinin daha uygun olduğu kabul edilmektedir. Bu sebeple, ikinci kuşak panel birim kök testlerinden olan Pesaran (2007)'ın panel birim kök testleri uygulanmıştır.

\section{Panel Birim Kök Testi}

Analize konu olan ülkeler arasında yatay kesit bağımlılığı saptandığı için analizde sapmalı tahminlerden kaçınmak adına, ikinci kuşak panel birim kök testleri kullanılmıştır. Literatürde bu testlerden en çok kullanılan CIPS (Cross-Sectionally Im, Pesaran and Shin) ve CADF (Cross-Sectionally Augmented Dickey Fuller) panel birim kök testleridir. Bu çalışmada Pesaran'ın (2007) kesit açısından genişletmiş olduğu CIPS panel birim kök testi 
kullanılmıştır. Im, Pesaran ve Shin (2003) çalışmasına dayanan bu testte her bir seri için iki varsayım kullanılmıştır. Bu varsayımlar doğrultusunda temel denklem şu şekildedir:

$\Delta y_{i t}=\left(1-\phi_{i}\right) \mu_{i}+\phi_{i} y_{i, t-1}+u_{i t} ; t=1,2, \ldots, T ; i=1,2, \ldots, N$

Hata terimi ise $u_{i t}=Y_{i} f_{t}+\varepsilon_{i t}$ biçiminde yazılır. $f_{t}$; gözlenemeyen ortak unsuru ifade etmekte olup her zaman durağan olduğu varsayılmaktadır. $\varepsilon_{i, t}$ ise seriye özgü bir unsur niteliğindedir ve bağımsız bir şekilde dağılmaktadır. Modeldeki yatay kesit bağımlılı̆̆ı, gözlenemeyen ortak unsurun varlığından kaynaklanmaktadır. Modelin temel denklemi şu şekildedir:

$\Delta y_{i t}=\alpha_{i}+\beta_{i} y_{i, t-1}+Y_{i} f_{t}+\varepsilon_{i t}$

Denklem 10'da Pesaran'ın (2007) çalışmasından hareketle dinamik liner heterojen panel veri modeli $\alpha_{i}=\left(1-\phi_{i}\right) \mu_{i}, \beta_{i}=-\left(\left(1-\phi_{i}\right)\right.$ ve $\Delta y_{i t}=y_{i t}-y_{i, t-1}$ şeklinde yazılır. $\lambda_{i} \neq 0$ ve $\mathrm{N} \rightarrow \infty$ durumunda, ortak unsurun $\dot{y}_{t}$ ve $\dot{y}_{t}{ }^{\prime}$ nin gecikmeli değerleri $\left(\dot{y}_{t-1}, \dot{y}_{t-2}, \ldots\right)$ ile yaklaştırılabileceği vurgulanmaktadır. Modeldeki her yatay kesitin $u_{i t}{ }^{\prime}$ deki olası otokorelasyonu göz ardı etmemek için ortak unsur ý, ve $\Delta y_{t}^{\prime}$ nin gecikmeli değerleri $\left(\Delta \dot{y}_{t-1}, \Delta \dot{y}_{t-2}, \ldots\right)$ ile yaklaştırılabilir (Pesaran, 2007: s.268).

CADF testinin $\mathrm{H}_{0}$ ve alternatif hipotezleri şu şekildedir:

$H_{0}: b_{i}=0, i=1,2,3, N$ (Birim kök yoktur) ve

$H_{1}: b_{i}<0, i=1,2,3, N_{1}, b_{i}=0, \quad i=N_{1}+1, N_{1}+2, \ldots \ldots, N$ (Birim kök vardır) şeklindedir.

CADF panel birim kök testinde $b_{i}$ katsayılarına ait $\mathrm{t}$ değerleri bulunur. $\mathrm{Bu} \mathrm{t}$ değerleri Pesaran'ın (2007) çalışmasındaki tablo değerleriyle karşılaştırılır. Hesaplanan CADF test istatistik değerleri kritik tablo değerlerinden mutlak değer olarak büyük olması durumunda temel hipotez (seride birim kök yoktur) reddedilmekte ve panelin geneli için alternatif hipotez (seride birim kök vardır) kabul edilmektedir. Pesaran'a göre CADF panel birim kök testi $\mathrm{N}>\mathrm{T}$ ve $\mathrm{T}>\mathrm{N}$ olduğu her iki durumda da geçerlidir (Pesaran, 2007: 269).

CIPS panel birim kök testindeki $\mathrm{t}$ istatistik değerleri Denklem 11'deki formülle elde edilmektedir (Pesaran, 2007: s.269). Pesaran (2007), tüm serilerin aritmetik ortalamalarını hesaplayarak CIPS istatistiğini şu şekilde elde etmektedir:

$\operatorname{CIPS}^{*}(N, T)=\overline{\operatorname{CADF}^{*}}=\frac{\sum_{i=1}^{N} C A D F_{i f}^{*}}{N}$

Panel birim kök testi sonucunda CIPS istatistiği ve kritik değerler Tablo 5'te verilmiştir

Tablo 5. Panel Birim Kök Testi Sonuçları

\begin{tabular}{cccccc}
\hline \multirow{2}{*}{ Değişkenler } & \multicolumn{3}{c}{ CIPS } & \multicolumn{3}{c}{ Kritik Değer } \\
\cline { 2 - 6 } & Düzey & $\Delta$ & $10 \%$ & $5 \%$ & $1 \%$ \\
\hline FRE & $-2.325^{*}$ & $-2.800^{* * *}$ & -2.22 & -2.37 & -2.66 \\
KOF & -1.930 & $-3.989^{* * *}$ & -2.22 & -2.37 & -2.66 \\
GDP & -1.575 & $-2.332^{*}$ & -2.22 & -2.37 & -2.66 \\
GOV & $-2.470^{* *}$ & $-3.026^{* * *}$ & -2.22 & -2.37 & -2.66 \\
\hline
\end{tabular}

Not: ${ }^{* *},{ }^{* *}$ ve ${ }^{*}$ sirasıyla $\% 1, \% 5$ ve $\% 10$ anlamlılık düzeyini ifade etmektedir. Gecikme değeri ise 3'tür. 
Tablo 5'teki panel birim kök testi sonuçlarına bakıldığında, serilerin genel olarak birinci farkı alındıktan sonra durağan hale geldikleri yani I(1) oldukları görülmektedir.

\section{Breusch-Pagan LM Testi}

Çalışmadaki modele uygun tahminci seçiminde, bireysel ve zaman etkilerinin belirlenmesi için LM testi uygulanmıştır. LM testinde üç farklı model tahmin edilmektedir. Bu modellerde; bireysel etkilerin $\left(\mathrm{LM}_{1}\right)$, zaman etkilerinin $\left(\mathrm{LM}_{2}\right)$ ve hem bireysel hem zaman etkilerin (LM) rassallığ 1 test edilmektedir.

$\mathrm{LM}_{1}$ testinde; bireysel etkiler yoktur şeklindeki $H_{0}: \sigma_{\mu}^{2}=0$ hipotezi, $\mathrm{LM}_{1}$ test istatistiği ile sınanmaktadır. LM1 istatistiği, Denklem 12' de görüldüğü gibi hesaplanmaktadır.

$L M_{1}=\frac{N . T}{2 .(T-1)}\left[\frac{\sum_{i=1}^{N}\left(\sum_{t=1}^{T} \widehat{u}_{i t}\right)^{2}}{\sum_{i=1}^{N} \sum_{t=1}^{T} \widehat{u}_{i t}{ }^{2}}-1\right]^{2}$

Denklem 12'de N; yatay kesit boyutunu, $\mathrm{T}$; zaman boyutunu, $\hat{u}$; hata terimlerinin tahminlerini ifade etmektedir. Breusch-Pagan LM testi ile bulunan olasılık değeri, 0.05 'ten küçük olduğunda, Ho reddedilir ve bireysel etkilerin rassal olduğu sonucuna ulaşılır.

$\mathrm{LM}_{2}$ testinde $H_{0}: \sigma_{\lambda}^{2}=0$ (zaman etkileri yoktur) hipotezi, $\mathrm{LM}_{2}$ istatistiği ile sinanmaktadır. $\mathrm{LM}_{2}$ istatistiği, Denklem 13' de yer alan formül yardımıyla hesaplanmaktadır.

$L M_{2}=\frac{N \cdot T}{2 \cdot(N-1)}\left[\frac{\sum_{t=1}^{T}\left(\sum_{n=1}^{T N} \widehat{u}_{i t}\right)^{2}}{\sum_{i=1}^{N} \sum_{t=1}^{T} \hat{u}_{i t}{ }^{2}}-1\right]^{2}$

$\mathrm{Bu}$ formülde N; yatay kesit sayısını, $\mathrm{T}$; zaman boyutunu, $\hat{u}$; hata terimlerinin tahminini ifade etmektedir. Bu test ile elde edilen olasılık değerinin, 0.05 'ten küçük olduğu durumda $\mathrm{H}_{0}$ reddedilmekte ve zaman etkilerinin rassal olduğu sonucuna varılmaktadır.

$L M=L M_{1}+L M_{1}$ testinde

$H_{0}: \sigma_{\mu}^{2}=\sigma_{\lambda}^{2}=0$ (Bireysel etkiler ve zaman etkileri yoktur)

$H_{1}: \sigma_{\mu}^{2} \neq 0$ veya $\sigma_{\lambda}^{2} \neq 0$ yada her ikisi de $\neq 0$ (Etkilerden en az biri ya da her ikisi rassaldır).

Elde edilen olasıllk değeri, $0.05^{\prime}$ ten küçük ise $\mathrm{H}_{0}$ reddedilmekte ve etkilerin her ikisinin de rassal olduğu sonucuna ulaşılmaktadır. LM test sonuçları Tablo 6' da yer almaktadır:

Tablo 6. LM Testleri: Model: FRE $=f(K O F, G D P, G O V)$

\begin{tabular}{ccc}
\hline Test & Olasılık Değeri & Karar \\
\hline $\mathrm{LM}_{1}$ & 0.000 & Bireysel Etkiler Rassaldır. \\
$\mathrm{LM}_{2}$ & 0.011 & Zaman Etkileri Rassal Rassaldır. \\
$\mathrm{LM}$ & 0.000 & Bireysel Etkiler ve Zaman Etkileri Rassaldır. \\
\hline
\end{tabular}

Tablo 6'daki sonuçlara göre, bireysel ve zaman etkilerinin rassal olduğu sonucuna ulaşılmaktadır.

Hausman Testi 
Ekonometrik model tahmin edilirken ortaya çıkabilecek değişen varyans ve oto-korelasyon sorunları, regresyon tahminlerini gerçekçi değerlerden uzaklaştırabileceği için otokorelasyon ve değişen varyans testleri uygulanmıştır. Buna ek olarak, katsayıların birimlere veya birimler ile zamana göre değiştiğinin varsayıldığı sabit veya tesadüfi etkiler modelleri arasında seçim yapabilmek amacıyla serilere Hausman testi uygulanmıştır. Söz konusu testler sonucunda elde edilen sonuçlar Tablo 7' de yer almaktadır.

Tablo 7. Hausman Test İstatistiği, Oto-Korelasyon ve Değişen Varyans Sonuçları

\begin{tabular}{ccc}
\hline Testler & Hipotezler & Yeni Sanayileşen \\
& Ülkeler
\end{tabular}

Ho: Tesadüfi etkiler modeli

Hausman Test İstatistiği

uygundur

Oto- Korelasyon

(Bhargava, Franzini

ve Narendranathan Testi)

Değişen Varyans

(Levene, Brown ve Forsythe

Testi)
$\mathrm{H}_{1}$ Sabit etkiler modeli uygundur

$\mathrm{H}_{0}$ : Otokorelasyon sorunu yoktur.

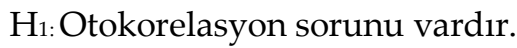

Baltagi-Wu

0.941

Durbin-Watson 0.646

$\mathrm{H}_{0}$ : Değişen varyans sorunu yoktur

$\mathrm{H}_{1}$ : Değişen varyans sorunu vardır
$\mathrm{W} 0=17.826 \mathrm{df}(9,140)$

$\operatorname{Pr}>\mathrm{F}=(0.000)^{* * *}$

Tablo 7'de yer alan Hausman test istatistiği sonuçlarına bakıldığında olasılık değerlerinin 0.319 olduğu görülmekte ve bu değerin 0.05 'ten büyük olması sebebiyle $\mathrm{H}_{0}$ hipotezi reddedilememektedir. Dolayısıyla tesadüfi etkiler modeli uygun olmaktadır. Ayrıca otokorelasyon problemine yönelik elde edilen test istatistiği sonuçlarındaki değerler (Durbin Watson için 0.646 ve Baltagi Wu için 0.941) kritik değer olan 2'den küçüktür. Dolayısıyla $\mathrm{H}_{0}$ hipotezi reddedilmektedir. $\mathrm{Bu}$ nedenle tesadüfi etkiler modelinde birinci seviyede otokorelasyon varlığı söz konusudur. Son olarak, değişen varyans testi sonucunda elde edilen 17.826 istatistik değeri 9,140 serbestlik dereceli $\mathrm{F}$ tablosu ile karşılaştırıldığında $\mathrm{H}_{0}$ hipotezi reddedilmektedir. Böylece değişen varyans sorunu olduğu sonucuna varılmaktadır (Yerdelen Tatoğlu, 2013: s.224).

\section{Driscoll-Kraay Model Tahmini}

Driscoll-Kraay (1998), büyük zaman boyutunun söz konusu olduğu durumda, standart parametrik olmayan (nonparametrik) zaman serisi kovaryans matris tahmincilerinin hem yatay kesit bağımlılığının hem de dönemsel korelasyonun bütün genel biçimleri için dirençli olacak biçimde güçlendirilebileceğini ortaya koymuştur. Driscoll ve Kraay (1998), Newey- 
West'in (1987) çalışmasını baz almakta; ve bu nedenle yatay kesit ortalamalarına benzer bir düzeltme uygulamaktadır. Bu sayede kovaryans matris tahmincilerinin tutarlılığı, düzeltilen standart hata tahminleri tarafından sağlanmaktadır. Bu durum, yatay kesit boyutundan (N) bağımsızdır; yani N sonsuza gitse dahi geçerlidir. Driscoll-Kraay metodolojisi hem sabit hem de tesadüfi etki modelleri için kullanılmaktadır. Bu tahminci heteroskedasite varlığında yatay kesit ve zaman boyutlarının büyük olduğu durumlarda dahi, tutarlı ve dirençli standart hatalar oluşturmaktadır (Yerdelen Tatoğlu, 2020: s.335).

Denklem 14 'te yer alan modelde,

$Y_{i t}=\beta X_{i t}+u_{i t} \quad i=1, \ldots, N ; t=1, \ldots, T$

otokorelasyonlu ve heteroskedastik hata teriminin mevcut olduğu varsayımı altında, Havuzlanmış En Küçük Kareler (HEKK) yöntemi yardımıyla tutarlı parametre tahminleri Denklem 15'te görüldüğü gibi yapılabilmektedir.

$\widehat{\beta}=\left(X^{\prime} X\right)^{-1} X^{\prime} Y$

Parametre tahminlerine ait standart hatalar, dirençli (asimptotik) kovaryans matrisinin köşegen elemanlarının karekökleri aracılığıyla bulunmaktadır. Driscoll-Kraay varyans kovaryans matrisi,

$V(\hat{\beta})=\left(X^{\prime} X\right)^{-1} \widehat{S_{T}}\left(X^{\prime} X\right)^{-1}$

iken $\widehat{S_{T}}$, şu şekilde tanımlanır:

$\widehat{S_{T}}=\widehat{\Omega}_{0}+\sum_{j=1}^{m(T)} w(j, \ddot{0})\left[\widehat{\Omega}_{j}+\widehat{\Omega}_{j}^{\prime}\right]$

Burada $m(T)$, otokorelasyon açısından gecikme uzunluğunu ifade etmektedir. $W(j, m(T))=$ $\left.1-\frac{j}{m(T)}+1\right)$ şeklinde gösterilen Bartlett ağırlıkları, pozitif tanımlı bir $\widehat{S_{T}}$ 'yi beraberinde getirmekte ve örnek otokovaryans foksiyonunda yüksek mertebeden gecikmelerin düşük ağırlıklara sahip olmasına olanak tanımaktadır. $(K+1) x(K+1)$ boyutlu $\widehat{\Omega}_{j}$ matrisi, Denklem 18'deki gibi ifade edilmektedir (Yerdelen Tatoğlu, 2020: s.336);

$\widehat{\Omega}_{j}=\sum_{t=j+1}^{T} h_{t}(\hat{\beta}) h_{t-j}(\hat{\beta})^{\prime}$

Burada $h_{t}(\hat{\beta})$ değeri, Denklem 19 yardımıyla hesaplanmaktadır:

$h_{t}(\hat{\beta})=\sum_{j=1}^{m(T)} w(j, \ddot{o})(\hat{\beta})$

Tüm birimler için $\mathrm{t}$ moment koşullarının karesi $h_{i t}(\hat{\beta})$, çeşitli T’leri olan N'ler için elde edilmektedir. Havuzlanmış EKK ile yapılan tahminde birimlerin ortogonallik koşulları $h_{t}(\hat{\beta})$, lineer regresyonun boyutu $(K+1) \times 1$ olan moment koşullarıdır (Yerdelen Tatoğlu, 2020: s.336). Örneğin $h_{t}(\hat{\beta})$ değeri;

$h_{i t}(\hat{\beta})=X_{i t} \hat{u}_{i t}=X_{i t}\left(Y_{i t}-X^{\prime}{ }_{i t} \hat{\beta}\right)$

biçiminde ifade edilebilmektedir. Driscoll Kraay kovaryans matris tahmincisi, $h_{i t}(\hat{\beta})^{\prime}$ a ait yatay kesit ortalamalarının zaman serilerinde kullanılan Newey-West'in değişen varyans ve otokorelasyon mevcut olduğunda dirençli kovaryans matris tahmincisine eşittir. Yatay kesit ortalamaları temelindeki bu yöntemde, standart hata tahminlerinin yatay kesit sayılarından bağımsız bir biçimde tutarlı olduğu ortaya konulmaktadır. Driscoll ve Kraay buna koşut olarak, yatay kesit boyutunun sonsuza gittiği koşullarda dahi tutarlılığın mevcut olduğunu ve standart hata tahminlerinin uzamsal ve dönemsel korelasyonun tüm biçimlerinde dirençli 
olduğunu ortaya koymuştur (Yerdelen Tatoğlu, 2020: s.336). Analizde gerçekleştirilen Driscoll-Kraay Tahmin sonuçları Tablo 8'de verilmiştir.

Tablo 8. Driscoll-Kraay Standart Hatalı Model Tahmini

Bağımlı Değişken: FRE (Freedom House Endeksi)

\begin{tabular}{lllll}
\hline Değişkenler & Katsayı & Standart Hata & $\mathbf{t}$ & $\mathbf{P}>|\boldsymbol{t}|$ \\
\hline KOF (Küreselleşme Düzeyi) & $-0.711^{* * *}$ & 0.119 & -5.97 & 0.000 \\
GOV (Kamu Kesimi Büyüklüğü) & $0.758^{* * *}$ & 0.195 & 3.89 & 0.002 \\
GDP (Ekonomik Kalkınma) & $1.307^{* * *}$ & 0.336 & 3.89 & 0.002 \\
DUMMY (Kukla Değişken) & $-2.783^{* *}$ & 1.060 & -2.63 & 0.020 \\
SABiT TERIM & $84.291^{* * *}$ & 13.529 & 6.23 & \\
F(4,14) & 402.35 & & & \\
Prob>F & 0.0000 & & & \\
R2 & 0.0803 & & \\
\end{tabular}

Not: ${ }^{* * *}$ ve ${ }^{* *}$ sirasıyla $\% 1$ ve $\% 5$ anlamlılık düzeyini ifade etmektedir.

Tablo 8'de elde edilen tahmin sonuçlara göre, küreselleşme düzeyindeki 1 birimlik artışın demokratikleşme seviyesini 0.711 birim azalttığı görülmektedir. Diğer taraftan ekonomideki kamu kesimi büyüklüğünde meydana gelecek 1 birimlik artışın demokratikleşme seviyesini 0.758 birim; ekonomik kalkınma değişkenindeki \% 1'lik artışın ise demokratikleşme seviyesini 1.307 birim artırdığı gözlemlenmektedir. 2008 kukla değişkeninin etkileri yorumlanacak olursa demokratikleşmenin 2008 sonrası dönemde 2008 öncesine kıyasla daha düşük seyrettiği, 2008 yılı sonrasındaki gelişmelerin bağımlı değişken olan demokratikleşme üzerinde negatif etkileri olduğu ifade edilebilir.

\section{Dumitrescue-Hurlin Panel Nedensellik Testi}

Bu çalışmada, seriler arasındaki nedensellik ilişkisi Dumitrescu ve Hurlin (2012)'in geliştirdikleri yöntemle sınanmıştır. Dumitrescu ve Hurlin testinin temel avantajları; ele alınan ülkeler arasındaki yatay kesit bağımlılığını dikkate alması, dengesiz panel veri setleri için de etkin sonuçlara ulaşabilmesi ve zaman $(\mathrm{T})$ ve yatay kesit boyutlarından $(\mathrm{N})$ hangisinin büyük olduğuna bakılmaksızın kullanılabilmesidir (Dumitrescu ve Hurlin, 2012: s.1457). Söz konusu testte, $X$ ve $Y$ arasındaki nedensellik ilişkisi, Denklem 21'deki gibi bir doğrusal model yardımıyla çözümlenebilmektedir:

$Y_{i t}=\alpha_{i}+\sum_{k=1}^{K} \beta_{i}^{k} Y_{i, t-k} \sum_{k=1}^{K} Y_{i}^{k} X_{i, t-k}+\varepsilon_{i, t} \mathrm{t}=1,2, \ldots, \mathrm{T} ; \mathrm{i}=1,2, \ldots, \mathrm{N}$ 
$\mathrm{Bu}$ denklemde yer alan $\mathrm{K}$, optimum gecikme uzunluğunu ifade etmektedir. Katsayıların homojenlik varsayımı ve serilerin durağan olma zorunluluğu ise bu yöntemin en önemli sınırlılıklarını oluşturmaktadır. Söz konusu teste ilişkin hipotezler şu şekildedir:

$H_{0}: \beta_{i}^{(k)}=0 \quad \forall i$ için, Bütün yatay kesitlerde $X^{\prime}$ ten $Y^{\prime}$ ye nedensellik ilişkisi yoktur.

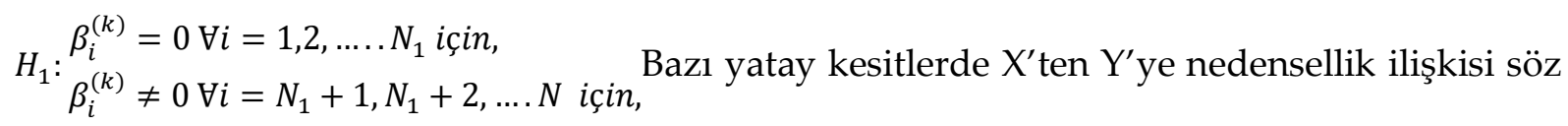
konusudur.

Dumitrescu ve Hurlin (2012) panel nedensellik testinde, önce her bir yatay kesit için bireysel Wald istatistikleri $\left(W_{i, T}\right)$ hesaplanmakta; ardından ise bu istatistiklerin aritmetik ortalamaları alınarak panele ait Wald istatistiği $\left(W_{N, T}^{H N C}\right)$ elde edilmektedir. Dumitrescu ve Hurlin (2012), zaman boyutu yatay kesit boyutundan büyük $(\mathrm{T}>\mathrm{N})$ olduğunda asimptotik dağılan (Denklem 22); tersi durumda $(\mathrm{T}<\mathrm{N})$ ise yarı asimptotik dağılan $\left(Z_{N}^{H N C}\right)$ test istatistiklerinin (Denklem 23) kullanımını tavsiye etmektedir.

$\begin{aligned} Z_{N, T}^{H N C} & =\sqrt{\frac{N}{2 K}} W_{N, T}^{H N C}-K \\ Z_{N}^{H N C} & =\frac{\sqrt{N}\left[W_{N, T}^{H N C}-N^{-1} \sum_{i=1}^{N} E\left(W_{i, T}\right)\right]}{\sqrt{N^{-1} \sum_{i=1}^{N} \operatorname{Var}\left(W_{i, T}\right)}}\end{aligned}$

Dumitrescu ve Hurlin (2012), Denklem 22 ve Denklem 23'deki test istatistikleri ve olasılık değerlerini Monte-Carlo simülasyonun yardımıyla elde etmektedir. Bu çalışmada, durağanlaştırılmış seriler ile Dumitrescu-Hurlin (2012) panel nedensellik testi yapılmıştır. Bu teste ilişkin sonuçlar Tablo 9'de yer almaktadır.

Tablo 9. Dumitrescu - Hurlin Panel Nedensellik Test Sonuçları

\begin{tabular}{|c|c|c|c|c|c|}
\hline No & Boş Hipotez $\left(\mathrm{H}_{0}\right)$ & W-ist. & Zbar-ist. & Olasılık & Karar \\
\hline 1 & $\mathrm{KOF} \neq \mathrm{FRE}$ & 3.383 & 0.601 & 0.548 & Nedeni değildir \\
\hline 2 & $\mathrm{FRE} \neq \mathrm{KOF}$ & 1.506 & -0.973 & 0.331 & Nedeni değildir \\
\hline 3 & GDP $\neq F R E$ & 4.266 & 1.341 & 0.180 & Nedeni değildir \\
\hline 4 & FRE $\neq \mathrm{GDP}$ & 2.320 & -0.291 & 0.771 & Nedeni değildir \\
\hline 5 & GOV $\neq F R E$ & 2.224 & -0.371 & 0.710 & Nedeni değildir \\
\hline 6 & $\mathrm{FRE} \neq \mathrm{GOV}$ & 3.699 & 0.866 & 0.387 & Nedeni değildir \\
\hline 7 & $\mathrm{GDP} \neq \mathrm{KOF}$ & 4.133 & 1.230 & 0.219 & Nedeni değildir \\
\hline 8 & $\mathrm{KOF} \neq \mathrm{GDP}$ & 4.574 & 1.599 & 0.110 & Nedeni değildir \\
\hline 9 & $\mathrm{GOV} \neq \mathrm{KOF}$ & 3.075 & 0.343 & 0.732 & Nedeni değildir \\
\hline 10 & $\mathrm{KOF} \neq \mathrm{GOV}$ & 4.013 & 1.129 & 0.259 & Nedeni değildir \\
\hline 11 & $\mathrm{GOV} \neq \mathrm{GDP}$ & 4.559 & 1.587 & 0.113 & Nedeni değildir \\
\hline 12 & GDP $\neq \mathrm{GOV}$ & 6.107 & 2.884 & 0.004 & Nedenidir \\
\hline
\end{tabular}


Tablo 9'daki sonuçlara bakıldığında sadece ekonomik kalkınmadan kamu kesimi büyüklüğüne doğru tek yönlü bir nedensellik ilişkisinin olduğu görülmektedir.

\section{Sonuç}

Bu çalışmada, Yeni Sanayileşen Ülkeler (NIC) için küreselleşme, ekonomik kalkınma ve ekonomideki kamu kesimi büyüklüğünün demokratikleşme seviyesi üzerindeki etkisi panel veri analizi yöntemiyle 2003-2017 arası döneme ait yıllık veriler kullanılarak test edilmiştir.

Çalışmada ülkeler arasında yatay kesit bağımlılı̆̆ı Frees (1995) testi ile analiz edilmiş ve yatay kesit bağımlılığının söz konusu olduğu görülmüştür. Bu nedenle çalışmanın ileriki aşamalarında, bu durumu dikkate alan yöntemler kullanılmıştır. Serilerin durağanlığ Pesaran (2007) tarafından geliştirilen CIPS panel birim kök testi ile incelenmiştir. Serilerin düzey değerlerinde durağan olmadığı ancak birinci farkları alındığında durağan hale geldiği görülmüsstür. Ayrıca, çalışmada Driscoll-Kraay Model Tahmini yaklaşımı kullanılmış ve nedensellik ilişkisi Dumitrescu ve Hurlin (2012) testiyle tahmin edilmiştir.

Elde edilen analiz sonuçlarına göre, yeni sanayileşen ülkelerde küreselleşmenin demokratikleşme seviyeleri üzerinde azaltıcı bir etkisinin bulunduğu; diğer taraftan ekonomik kalkınma ve kamu kesimi büyüklüğünün ise demokratikleşmeyi artırdığ1 sonucuna ulaşılmaktadır. Kukla değişkenin etkilerine bakıldığında, 2008 finansal krizinin model için bir kırılma noktasını temsil ettiği söylenebilir. Buna koşut olarak, kriz sonrasında güçlenen toplumsal çatışma ve ulusal güvenlik gibi küreselleşmenin yan etkilerinin politik istikrarsızlıkları artırarak; demokratikleşme üzerinde negatif etkiye sebep olup olmadığ gelecekte yapılacak çalışmalar için önemli bir araştırma konusu niteliğindedir. Ayrıca söz konusu ülkeler arasında demokratikleşmeyi önceleyenlerin, küreselleşmenin demokratikleşme üzerindeki negatif etkisi nedeniyle daha küreselleşme karşıtı politikalara yönelebileceği öngörülebilir. Ancak yeni sanayileşen ülkeler arasında yer alan Asya ülkeleri için bu ihtimal, halihazırdaki küreselleşme yanlısı tutumları (Milanovic, 2021: 19) nedeniyle düşüktür.

Diğer bir taraftan bulguların; küreselleşmenin demokratikleşmeyi teşvik ettiği, kamu kesimi genişlemesinin ise antidemokratikleşmeye yol açtığı yönündeki görüşler ile çeliştiği; kalkınmanın demokratikleşmeyi artırdığına yönelik literatürde yer alan hâkim görüşü ise desteklediği görülmektedir.

Analizde yeni sanayileşen ülkelerin ele alınmasının yanı sıra demokratikleşme üzerine etki edebilecek hem ulusal hem de uluslararası boyuttaki olgulara odaklanılması, çalışmanın özgünlügünü artırarak; literatüre katkı sunmaktadır. Ancak, küreselleşme ve demokratikleşmenin çok boyutlu niteliği, analiz sonuçlarının en önemli sınırlılığını oluşturmaktadır. Bu konuda yapılacak ileriki çalışmaların küreselleşmenin niteliğine ve farklı demokratikleşme endekslerine göre oluşturulması, bu alandaki literatürün genişlemesini sağlayacak bir adım olacaktır.

\section{Kaynakça}

Acaravcı, A., \& Erdoğan, S. (2015). Türkiye'de demokrasi, reel gelir ve dışa açıklık arasındaki uzun dönemli ve nedensel ilişkiler. Mustafa Kemal Üniversitesi Sosyal Bilimler Enstitüsü Dergisi, 12(31), 358-370. Retrieved from https://dergipark.org.tr/tr/pub/mkusbed/issue/19577/208965

Acemoğlu, D., \& Robinson, J. A. (2016). Diktatörlük ve demokrasinin ekonomik kökenleri. İstanbul: Bağlam Yayıncilik. 
Acemoglu, D., Johnson, S., Robinson, J. A., \& Yared, P. (2008). Income and democracy. American Economic Review, 98(3), 808-42. DOI: 10.1257/aer.98.3.808

Adsera A, \& Boix C. (2002). Trade, democracy, and the size of the public sector: the political underpinnings of openness. International Organization, 56(2): 229-62. DOI: https://doi.org/10.1162/002081802320005478

Alesina, A., \& Wacziarg, R. (1998). Openness, country size and government. Journal Of Public Economics, 69(3), 305-321. DOI:10.1016/S0047-2727(98)00010-3

Altıntaş, H., \& Mercan, M. (2015). Ar-Ge harcamalari ve ekonomik büyüme ilişkisi: OECD ülkeleri üzerine yatay kesit bağimliliği altinda panel eşbütünleşme analizi. Ankara Üniversitesi SBF Dergisi, 70(2), 345-376.

Baltagi, B. H. (2001). Econometric analysis of panel data (2nd ed). New York: John Wiley \& Sons.

Barnet, R. J., \& Cavanagh, J. (1995). Global dreams: imperial corporations and the new world order. Simon \& Schuster.

Bayar, Y., \& Alakbarov, N. (2016). Corruption and foreign direct investment inflows in emerging market economies. Ecoforum Journal, 5(2). 165-180.

Bhargava, A., Franzini, L., \& Narendranathan, W. (1982). Serial correlation and the fixed effects model. The Review of Economic Studies, 49(4), 533-549. DOI: https://doi.org/10.2307/2297285

Boix, C. (2003). Democracy and redistribution. Cambridge University Press.

Boix, C. (2011). Democracy, development, and the international system. American Political Science Review, 105(4), 809-828. DOI: https://doi.org/10.1017/S0003055411000402

Boix, C., \& Garicano, L. (2001). Democracy, inequality, and country-specific wealth. University of Chicago.

Bozkurt, V. (2020). Küreselleşen dünyada toplumsal meseleler. İstanbul Üniversitesi Açık ve Uzaktan Eğitim Fakültesi. Erişim Adresi http://auzefkitap.istanbul.edu.tr/kitap/sosyoloji_lisans_ao/kuresellesen_dunyada_toplumsal_mesel eler.pdf.

Breusch, T.S. \& Pagan, A. (1980), The lagrange multiplier test and its applications to model specification tests in econometrics, Review of Economic Studies, 47(1), 239-253. DOI: https://doi.org/10.2307/2297111

Brown, M. B., \& Forsythe, A. B. (1974). The small sample behavior of some statistics which test the equality of several means. Technometrics, 16(1), 129-132.

Brune, N., Garrett, G., Guisinger, A., \& Sorens, J. (2001). The political economy of capital account liberalization. In Annual Meeting of the American Political Science Association, San Francisco.

Dam, M. M., \& Yıldız, B. (2016). BRICS-TM ülkelerinde AR-GE ve inovasyonun ekonomik büyüme üzerine etkisi: ekonometrik bir analiz. Akdeniz Üniversitesi İktisadi ve İdari Bilimler Fakültesi Dergisi, 16(33), 220-236. Retrieved from https://dergipark.org.tr/tr/pub/auiibfd/issue/32338/359349

De Macedo, J. B., Pereira, L. B., Martins, J. O., \& Jalles, J. T. (2013). Globalization, democracy and development (No. w19575). National Bureau of Economic Research. Retrieved from https://www.nber.org/system/files/working_papers/w19575/w19575.pdf

Decker, J. H., \& Lim, J. J. (2009). Democracy and trade: an empirical study. Economics of Governance, 10(2), 165-186. DOI: https://doi.org/10.1007/s10101-008-0053-8 
Destek, M. A. (2016). Renewable Energy consumption and economic growth in newly industrialized countries: evidence from asymmetric causality test. Renewable Energy, 95, 478-484. DOI: https://doi.org/10.1016/j.renene.2016.04.049

Doces, J. A. (2006). Globalization and democracy: an empirical analysis using a simultaneous equation approach. Center for Globalization and Governance.

Doğan, A. (2005). Demokrasi ve ekonomik gelişme. Erciyes Üniversitesi İktisadi ve İdari Bilimler Fakültesi Dergisi, (25), 1-19. Retrieved from https://dergipark.org.tr/tr/pub/erciyesiibd/issue/5882/77821

Driscoll, J. C., \& Kraay, A. C. (1998). Consistent covariance matrix estimation with spatially dependent panel data. Review of Economics and Statistics, 80(4), 549-560. Retrieved from https://www.jstor.org/stable/2646837

Dumitrescu, E.I. \& Hurlin, C. (2012), “Testing for granger non-causality in heterogeneous panels", Economic Modelling, 29(4), 1450-1460. DOI: 10.1016/j.econmod.2012.02.014

Dutt, P., \& Mitra, D. (2002). Endogenous trade policy through majority voting: an empirical investigation. Journal of International Economics, 58(1), 107-133. Retrieved from https://faculty.insead.edu/pushan-dutt/documents//Paper12.pdf

Eichengreen B, \& Leblang D. (2007). Democracy and globalization. Bank for International Settlements, 9. DOI: https://doi.org/10.1111/j.1468-0343.2007.00329.x

Er, H. A. (1997). Development patterns of industrial design in the third world: a conceptual model for newly industrialized countries. Journal of Design History, 10(3), 293-307. DOI: https://doi.org/10.1093/jdh/10.3.293

Erdağ, R., \& Peker, K. (2014). Küreselleşme sürecinin demokrasi üzerine etkisi. Çankırı Karatekin Üniversitesi Sosyal Bilimler Enstitüsü Dergisi, 5(1), 211-220. Retrieved from https://dergipark.org.tr/tr/pub/jiss/issue/25892/272863

Eren, M. V., \& Çütcü, İ. (2018). Küreselleşmenin ekonomik büyümeye etkisi: türkiye üzerine ekonometrik bir analiz. Siyaset, Ekonomi ve Yönetim Araştırmaları Dergisi, 6(1) 47-61. Retrieved from https://dergipark.org.tr/tr/pub/seyad/issue/53362/709446

Falk, R. A. (1999). Predatory globalization: A Critique. Polity.

Fölster, S., \& Henrekson, M. (2001). Growth effects of government expenditure and taxation in rich countries. European Economic Review, 45(8), 1501-1520. Retrieved from https://www.ifn.se/Wfiles/wp/wp503.pdf

Freedom House, (2020). Erişim Adresi: https://freedomhouse.org/sites/default/files/202002/Methodology_FIW_2019_for_website, Erişim Tarihi: 18.11.2020.

Frees, E. W. (1995). Assessing cross-sectional correlation in panel data. Journal of Econometrics, 69(2), 393-414. DOI: https://doi.org/10.1016/0304-4076(94)01658-M

Garrett, G. (2000). The causes of globalization. Comparative Political Studies, 33(6-7), 941-991. DOI: https://doi.org/10.1177\%2F001041400003300610

Ghazali, A., \& Ali, G. (2019). Investigation of key contributors of CO2 emissions in extended STIRPAT model for newly industrialized countries: a dynamic common correlated estimator (DCCE) approach. Energy Reports, 5, 242-252. DOI: 10.1016/j.egyr.2019.02.006

Gray, J. (1999). Sahte şafak: küresel kapitalizmin aldatmacaları (Çev. G. Güven). İstanbul: OM Yayıncılık.

Gujarati, D. N. (1999) Temel ekonometri (7. Basım, Eylül 2010). (Çev. Ü. Şenesen ve G. Günlük Şenesen). İstanbul: Literatür Yayıncılık. 
Gurgul, H. \& Lach, L. (2014), Globalization and economic growth: evidence from two decades of transition in CEE, Economic Modelling, 36, 99-107. Retrieved from https://mpra.ub.unimuenchen.de/52231/1/MPRA_paper_52231.pdf

Hardt, M. \& Negri, A., (2001). İmparatorluk, (Çev. A. Yılmaz). İstanbul: Ayrıntı Yayınları.

Hausman, J. A. (1978). Specification tests in econometrics. Econometrica: Journal of the Econometric Society, 46(6), 1251-1271. DOI: https://doi.org/10.2307/1913827

Hayaloğlu, P., Kalaycı, C., \& Artan, S. (2015). Küreselleşme farklı gelir grubundaki ülkelerde ekonomik büyümeyi nasıl etkilemektedir. Eskişehir Osmangazi Üniversitesi İ̈BF Dergisi, 10(1), 119152. Retrieved from https://dergipark.org.tr/tr/pub/oguiibf/issue/56487/785422

Held, D. (1995). Ulus devletin çöküşü. yeni zamanlar: 1990'larda politikanın değişen çehresi, (Der. S. Hall ve M. Jacques), (Çev. A. Yılmaz), İstanbul: Ayrıntı Yayınları

Held, D., McGrew, A., Goldblatt D. \& Perraton, J. (1999). Global transformations: politics, economics and cultures. Cambridge: Polity Press.

Hirst, P. \& Thompson, G. (1998). Küreselleşme sorgulanıyor. Ankara: Dost Yayınevi.

Hossain, M. S. (2011). Panel estimation for CO2 emissions, energy consumption, economic growth, trade openness and urbanization of newly industrialized countries. Energy Policy, 39(11), 6991-6999. DOI: 10.1016/j.enpol.2011.07.042

Im K.S., Pesaran M.H. \& Shin Y. (2003). Testing for unit roots in heterogenous panels. Journal of Econometrics, 115, ss. 53-57. DOI: 10.1016/S0304-4076(03)00092-

Kılıç, M. (2020). Portföy yatırımları ve doğrudan yabancı yatırımların ekonomik büyüme üzerindeki etkisi: yeni sanayileşen ülkeler örneği. Avrasya Sosyal ve Ekonomi Araştırmaları Dergisi, 7(8), 45-55. Retrieved from https://dergipark.org.tr/tr/pub/asead/issue/56449/766482

Kıvılcım, F. (2013). Küreselleşme kavramı ve küreselleşme sürecinin gelişmekte olan ülke türkiye açısından değerlendirilmesi. Sosyal ve Beşeri Bilimler Dergisi, 5(1), 219-230. Retrieved from https://dergipark.org.tr/tr/pub/sobiadsbd/issue/11355/135742

KOF Globalisation Index, 2020. Erişim Adresi https://kof.ethz.ch/en/forecasts-andindicators/indicators/kof-globalisation-index.html (Erişim Tarihi: 16.11.2020)

Kollias, C., \& Paleologou, S. M. (2016). Globalization and democracy: a disaggregated analysis by income group. Global Economy Journal, 16(2), 213-228. DOI: 10.1515/gej-2015-0048

Kutlay, M., \& Öniş, Z. (2020). Otoriter kapitalizmin yükselişi: değişen küresel dengeler ve demokrasinin geleceği üzerine. Ekonomi ve Toplum (120), 42-53.

Landau, D. (1983). Government expenditure and economic growth: a cross-country study. Southern Economic Journal, 49(3), 783-792. DOI:10.2307/1058716

Levene, H. (1960). Robust tests for equality of variances. Olkin I., Ghurye G., Hoeffding W., Madow W. G. ve Mann H. B. (Ed.), Contributions to probability and statics içinde. (s. 278-292). California: Stanford University of Press

Li, Q., \& Reuveny, R. (2003). Economic Globalization and democracy: an empirical analysis. British Journal of Political Science, 33(1), 29-54. DOI: 10.1017/S0007123403000024

Linden, M., \& Ray, D. (2017). Aggregation bias-correcting approach to the health-income relationship: life expectancy and GDP per capita in 148 countries, 1970-2010. Economic Modelling, 61, 126-136. DOI: 10.1016/j.econmod.2016.12.001 
Loizides, J., \& Vamvoukas, G. (2005). Government expenditure and economic growth: evidence from trivariate causality testing. Journal of Applied Economics, 8(1), 125-152. DOI: https://doi.org/10.1080/15140326.2005.12040621

López-Córdova, J. E., \& Meissner, C. M. (2005). The globalization of trade and democracy, 1870-2000 (No. w11117). National Bureau of Economic Research. Retrieved from https://www.nber.org/system/files/working_papers/w11117/w11117.pdf

Majaski, C. (t.y.). Newly industrialized country, Retrieved from https://www.investopedia.com/terms/n/newly-industrialized-country.asp.

Milanovic, B. (2021). Kapitalizm, Tek Başına. (Çev. M. Pirili ve M. Uzbay). Ankara Efil Yayınevi.

Milner, H. V., \& Kubota, K. (2005). Why the move to free trade? democracy and trade policy in the developing countries. International Organization, 59(1), 107-143. Retrieved from https://www.princeton.edu/ hmilner/forthcoming\%20papers/LDCdem_IO.pdf

Milner, H. V., \& Mukherjee, B. (2009). Democratization and economic globalization. Annual Review of Political Science, 12, 163-181. DOI: https://doi.org/10.1146/annurev.polisci.12.110507.114722

Newey, W. K., \& West, K. D. (1987). Hypothesis testing with efficient method of moments estimation. International Economic Review, 777-787. DOI: https://doi.org/10.2307/2526578

Nurudeen, A., \& Usman, A. (2010). Government expenditure and economic growth in nigeria, 19702008: a disaggregated analysis. Business and Economics Journal, 4, 1-11. Retrieved from https://mpra.ub.uni-muenchen.de/69814/1/MPRA_paper_69814.pdf

Olimpia, N., \& Stela, D. (2017). Impact of globalisation on economic growth in romania: an empirical analysis of its economic, social and political dimensions. Studia Universitatis "Vasile Goldis" AradEconomics Series, 27(1), 29-40. DOI: 10.1515/sues-2017-0003

O'Rourke, K. H., \& Taylor, A. M. (2006). Democracy and protectionism (No. w12250). National Bureau of Economic Research. Retrieved from https://www.nber.org/system/files/working_papers/w12250/w12250.pdf

Papaioannou E. \& Siourounis, G. (2008). Democratization and growth. The Economic Journal, 118(532), 1520-1551. DOI: https://doi.org/10.1111/j.1468-0297.2008.02189.x

Pesaran M.H., (2007). A simple panel unit root test in the presence of cross-section dependence, Journal of Applied Econometrics 22, ss. 265-312. DOI: https://doi.org/10.1002/jae.951

Pesaran, M. H. (2021). General diagnostic tests for cross-sectional dependence in panels. Empirical Economics, 60, 13-50.

Polterovich, V., \& Popov, V. (2005). Democracy and growth reconsidered: why economic performance of new democracies is not encouraging. DOI: 10.2139/ssrn.1755005

Quinn, D. P. (2003). Capital account liberalization and financial globalization, 1890-1999: a synoptic view. International Journal of Finance $\mathcal{E}$ Economics, 8(3), 189-204. DOI: https://doi.org/10.1002/ijfe.209

Rigobon, R., \& Rodrik, D. (2005). Rule of law, democracy, openness, and income: estimating the interrelationships. Economics of Transition, 13(3), 533-564. DOI: https://doi.org/10.1111/j.14680351.2005.00226.x

Robinson, J. A. (2006). Economic development and democracy. Annual Review of Political Science, 9, 503-527. DOI: https://doi.org/10.1146/annurev.polisci.9.092704.171256

Rudra, N. (2005). Globalization and the strengthening of democracy in the developing world. American Journal of Political Science, 49(4), 704-730. DOI: https://doi.org/10.1111/j.15405907.2005.00150.x 
Şahin, K. (2006). Küreselleşme demokrasiyi güçlendiriyor mu?. Akademik İncelemeler Dergisi (AID), 1(2), 1-17. Retrieved from https://dergipark.org.tr/tr/pub/akademikincelemeler/issue/1558/19161

Shahzad, U., Doğan, B., Sinha, A., \& Fareed, Z. (2020). Does export product diversification help to reduce energy demand: exploring the contextual evidences from the newly industrialized countries. Energy, 214, 118881. Retrieved from https://mpra.ub.unimuenchen.de/103718/1/MPRA_paper_103718.pdf

Steger, M. B. (2013). Küreselleşme. (Çev. A. Ersoy). Ankara: Dost Kitabevi.

Topuz, S. K. (2016). Ülkelerin küreselleşme demokrasi ve ekonomik büyüklük göstergeleri ile cinsiyet temelli gelişme endeksi arasındaki ilişkinin incelenmesi. Gazi Universitesi Iktisadi ve Idari Bilimler $\begin{array}{lllll}\text { Fakultesi Dergisi, } & \text { 18(3), } & \text { R79. } & \text { Retrieved }\end{array}$ https://dergipark.org.tr/tr/pub/gaziuiibfd/issue/28284/300446

Uddin, M. M. M. (2015). Causal relationship between agriculture, industry and services sector for GDP growth in Bangladesh: an econometric investigation. Journal of Poverty, Investment and Development, 8 , 124-129. Retrieved from https://citeseerx.ist.psu.edu/viewdoc/download?doi=10.1.1.676.6370\&rep=rep1\&type=pdf

United Nations. (2019). World economic situation and prospects, Statistical Annex.

Verter, N., \& Osakwe, C. N. (2015). Economic globalization and economic performance dynamics: some new empirical evidence from Nigeria. Mediterranean Journal of Social Sciences, 6(1), 87-87. DOI: $10.36941 / \mathrm{mjss}$

Villaverde, J. \& Maza, A. (2011), Globalization, growth and convergence, World Economy, 34(6), $952-$ 971. DOI: https://doi.org/10.1111/j.1467-9701.2011.01359.x

Weiss, J. (1988). Industry in developing countries. Londra: Routledge

Yerdelen Tatoğlu, F. (2013). Panel veri ekonometrisi: stata uygulamalı. İstanbul: Beta Yayınları.

Yerdelen Tatoğlu, F. (2020). Panel veri ekonometrisi: stata uygulamalı (Genişletilmiş 5. Baskı). İstanbul: Beta Yayınları.

Zeren, F., \& Koç, M. (2014). The nexus between energy consumption and financial development with asymmetric causality test: new evidence from newly industrialized countries. International Journal of Energy Economics and Policy, 4(1), 83-91. Retrieved from https://www.acarindex.com/dosyalar/makale/acarindex-1423903765.pdf

Zhang, S., Liu, X., \& Bae, J. (2017). Does trade openness affect CO2 emissions: evidence from ten newly industrialized countries?. Environmental Science and Pollution Research, 24(21), 17616-17625. DOI: $10.1007 / \mathrm{s} 11356-017-9392-8$

Zortuk, M., \& Beşer, B. (2014). Dışa açıklık ve demokratik yapının kamu kesimi büyüklüğü üzerindeki etkisi: rodrik hipotezine geçiş ekonomilerinden kanit. Ege Akademik Bakış, 14(3), 345-359. Retrieved from https://dergipark.org.tr/tr/pub/eab/issue/39931/474340 